\title{
Mew Gull Larus canus breeding in a residential area of Malmö, Sweden
}

\author{
Häckning av fiskmås Larus canus \\ i ett bostadsområde i Malmö
}

\author{
César Chávez Villavicencio' ${ }^{1}$ iD \& Fernanda Márquez Bahamonde ${ }^{2}$ \\ 1 Programa Doctorado Biología y Ecología Aplicada, Universidad Católica del Norte (Chile), Larrondo 1281, Coquimbo, \\ Región de Coquimbo, Chile | cchavez@ucn.cl²Berguvsgatan 11B, 21559 Malmö, Sweden | marbaha102@gmail.com
}

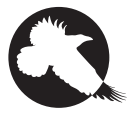

THE MEW GULL Larus canus is both a coastal and inland breeder and can be found on many different substrates, including man-made structures. It is known since long to nest in urban areas of Sweden, but neither the number of urban breeding pairs nor their behaviour have been well documented. We made some observations of breeding Mew Gulls in the city of Malmö in south Sweden and asked the chair of the tenant owners' association that comprised one of the buildings with Mew Gull nest about the tenants' experience of the species. Some perceive Mew Gulls as harmful because they dirty the roofs, leave a bad smell, are noisy, and defend their young with aggressive behaviours. Given the often-conflicting interests of gulls and humans, a better documentation of the nesting population in urban areas of Sweden, as well as their behaviour and interaction with people, is called for.

Keywords: animal-human conflict | urban birds | urban breeding

\section{Introduction}

The Mew Gull Larus canus is an abundant species that inhabits North America and Eurasia (Burger et al. 1996). It traditionally nests both along the coast and inland, either in colonies or in solitary pairs (Svensson et al. 1999, Skórka et al. 2006). Nests along the coast are located on rocky cliffs with vegetation, sandy beaches and pebbles, dunes, stacked debris from floods or tides, on islands, and on rocky islets (Burger et al. 1996, Snow \& Perrins 1998). Inland, the species nests on small islands in freshwater and saline lakes, swamps, stony beaches in streams, rivers, and man-made structures, such as industrial reservoirs, where it uses gravel extraction sites and sedimentation pools (Burger et al. 1996, Snow \& Perrins 1998, Svensson et al. 1999, Skórka 
et al. 2006). Mew Gulls can also be found nesting in nest-boxes made for other species (Burger et al. 1996).

It is known that both this and other gull species frequently breed in urban areas and in man-made structures. While there are systematic and quantitative data from the UK and Ireland (Raven \& Coulson 1997, Mitchell et al. 2004, Rock 2005), we have only found urban breeding mentioned very briefly for Sweden (Svensson et al. 1999, Rock 2005). We here report observations of breeding Mew Gulls in an urban area of Malmö in southern Sweden, including information about how human residents in the area perceive the birds. Given that humans often perceive urban gulls as a problem (Rock 2005), with our note we hope to stimulate the scientific community to carry out more thorough studies on the abundance and behaviour of seagulls nesting in urban areas in Sweden.

\section{Material and methods}

We found Mew Gull nests in a housing complex of Västra Söderkulla, Malmö ( $\left.55^{\circ} 34^{\prime} 6.98^{\prime \prime} \mathrm{N}, 13^{\circ} \mathrm{o}^{\prime} 35.96^{\prime \prime} \mathrm{E}\right)$, in an area of 2.2 ha (Figure 1). The height of the buildings

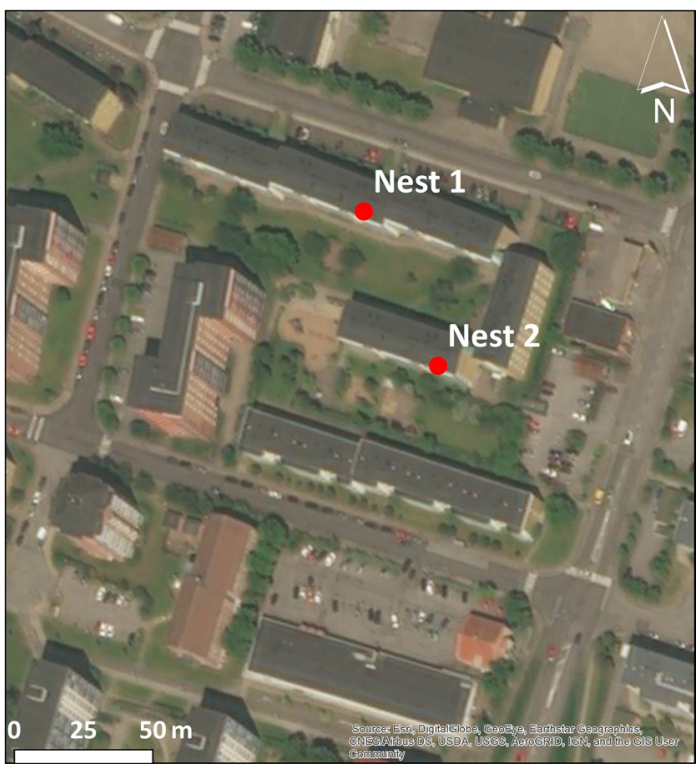

FIGURE 1. Location of Mew Gull Larus canus nests in a housing complex in Västra Söderkulla, Malmö, Sweden, in 2019. Nests 1 and 2 are indicated with red dots.

- Boplatser 2019 för fiskmåsar Larus canus i bostadsområdet Västra Söderkulla i Malmö. Bon 1 och 2 visas med röda cirklar. was approximately 10 to $12 \mathrm{~m}$ and the surface of the roofs reached 0.5 ha. Around and between the buildings were gardens with lawns, bushy vegetation and trees, as well as parking areas. There was constant movement of cars in the area and the noise of the vehicles was noticeable from any point. The closest distance to the sea is $4.8 \mathrm{~km}$ to the northwest.

The observations were made in July 2019. The first encounter with breeding Mew Gulls was casual, while the second was made after searching the surrounding area. Next, a nesting couple was chosen and their behaviour was observed, as well as their interaction with the people who inhabit the housing complex. This was carried out for four days. Finally, a person who lives in one of the buildings, and serves as chair of the tenant owners' association of the housing complex, was interviewed. He was asked about the presence of Mew Gulls in the areas, such as the approximate date of the beginning of the reproductive activity in these buildings and a preliminary perception of this species and their activity.

\section{Results}

Two breeding attempts were recorded on the roof of two of the eight buildings in the study area (Figure 1). Nest 1 was located between the rainwater collector channel and the roof of a balcony and contained three chicks (Figure 2). One of the parents fed the chicks at least twice between 10:00 and 13:00 and twice between 16:00 and 20:00. On one occasion during the day, one of the parents behaved aggressively towards a person who was walking at a distance of $28 \mathrm{~m}$ along the opposite sidewalk. The bird followed the person for 40 $\mathrm{m}$ fluttering over their head with characteristic shouts, without touching them, presumably to protect its territory. Nest 2 held two young in the stage of fledgling. One of them we found on the ground, calling while hiding among the vegetation.

The interview with the chairman of the tenant owners' association revealed that Mew Gulls have nested on these buildings at least since 2012. Many residents consider the species harmful to them because the roofs of the houses they nest on get dirty with faeces, leaving a bad smell. The gulls are also considered noisy and occasionally interact with people who rest in the courtyard, by stealing their food or showing aggressive 


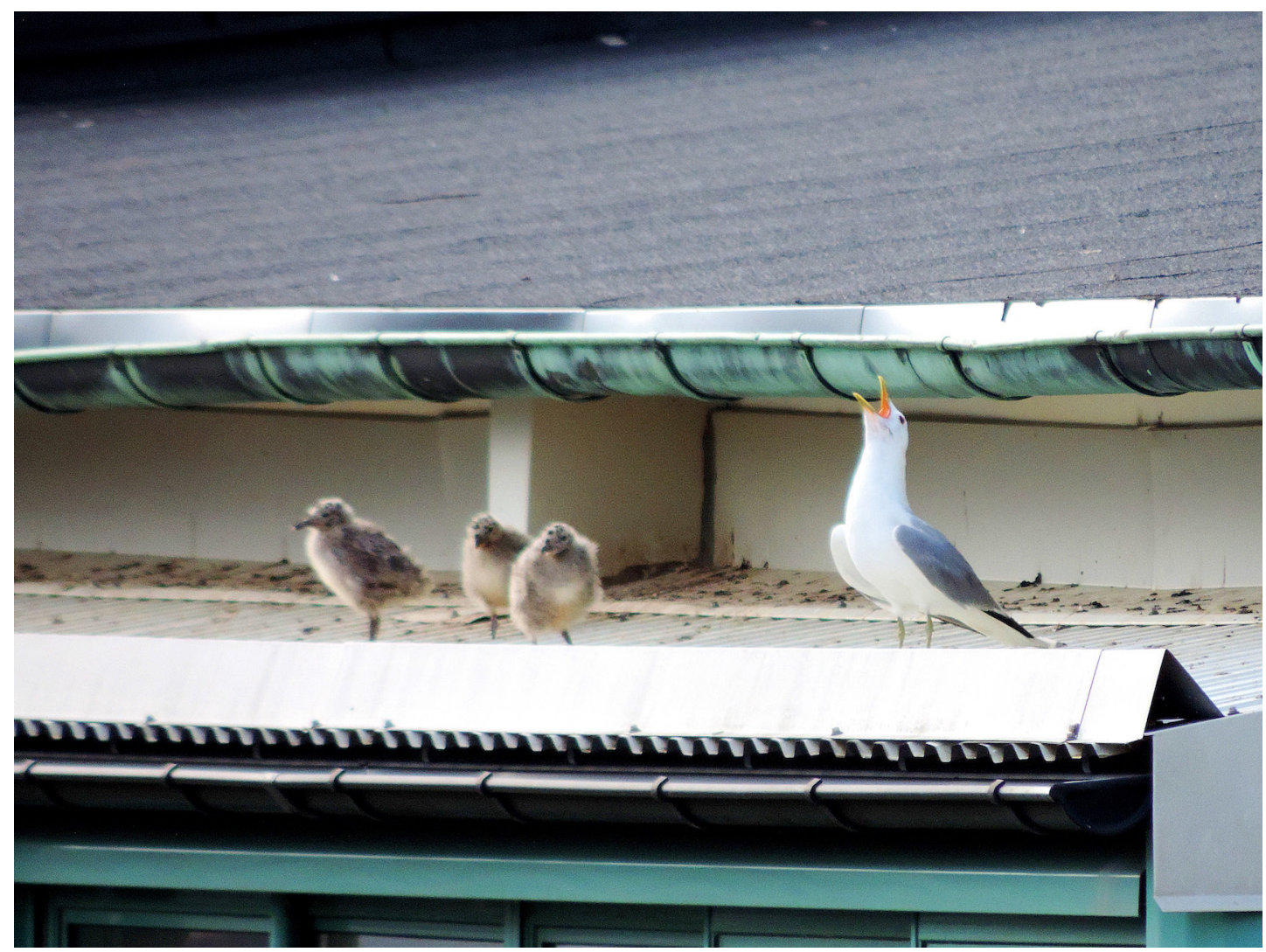

FIGURE 2. Three chicks and one parent of Mew Gull Larus canus at Nest 1 (see Figure 1) on the roof of a balcony of one of the buildings. Photo: César Chávez Villavicencio.

- Tre fiskmåsungar Larus canus och en förälder vid bo 1 (se figur 1) på ett balkongtak på en av byggnaderna. Foto: César Chávez Villavicencio.

behaviour towards people to defend their young. The chairman perceived that there are more of them today than in previous years. The maintenance staff for the housing complex, who can access the nests, regularly take the eggs and puncture them to empty the contents, which ensures that the Mew Gulls remain on the nest, incubating the empty eggs, without producing any young. This way, they mitigate the negative effects experienced by the residents during the rearing of Mew Gull chicks.

\section{Discussion}

Some urban gull populations have increased dramatically in numbers (Rock 2005, Chávez-Villavicencio 2014, Kroc 2018). Gull populations that inhabit urban areas often come in conflicts with the human population, because they are considered threats to properties and health, and because they cause a perceived loss of aesthetics (Belant 1997, Rock 2005), as found also in this study.

Mew Gulls are known to nest on roofs along the western coast of continental Europe from Norway to Portugal (Rock 2005). The nesting of gulls in urban areas may be associated with a good supply of food, high breeding success, and large amounts of suitable breeding habitats (Jones 1985, Rock 2005), combined with the ability of gulls to adapt to human-altered environments (Belant 1997). In Sweden, the Mew Gull population has been largely stable since the late 1980 os (Green et al. 2019), but we do not know of any estimates of the nesting population of Mew Gull in urban areas 
of Sweden. There is also need for more behavioural studies related to the interaction between Mew Gulls and humans in urban areas. Such information would be useful for a proper management of urban populations and could help mitigating the perceived problems of urban breeding gulls.

\section{Acknowledgements}

The authors thank Per-Ola Öreberg, chair of the tenant owners' association of the housing complex, for the interview, Max Persson for his help in translation, and the editor and two anonymous reviewers for improving an earlier version of the manuscript.

\section{References}

Belant JL. 1997. Gulls in urban environments: landscape-level management to reduce conflict. Landscape and Urban Planning 38: 245-258. https://doi.org/10.1016/So169-2046(97)00037-6

Chávez-Villavicencio C. 2014. Approach to breeding site selection of Kelp Gull (Larus dominicanus Lichtenstein 1823) in an urban area from Coquimbo region (Chile) and a new nesting substrate. The Biologist (Lima) 12: 33-44. (In Spanish with English summary.)

Burger J, Gochfeld M, Kirwan GM, Christie DA \& Garcia EFJ. 1996. Mew Gull (Larus canus). In: del Hoyo J et al. (eds). Handbook of the Birds of the World, Vol. 3: Hoatzin to Auks. Lynx Edicions, Barcelona.

Green M, Haas F \& Lindström Å. 2019. Monitoring population changes of birds in Sweden. Annual report for 2018. Department of Biology, Lund University. 92 pp. (In Swedish with English summary.)

Jones M. 1985. Distribution and activity of Common Gulls and Black-headed Gulls on grassland in Manchester. Bird Study 32: 104-112. https://doi.org/10.1080/00063658509476864

Kroc E. 2018. Reproductive ecology of urban-nesting Glaucous-Winged Gulls Larus glaucescens Vancouver, BC, Canada. Marine Ornithology 46: 155-164.

Mitchell PI, Newton SF, Ratcliffe N \& Dunn TE. 2004. Seabird Populations of Britain and Ireland: Results of the Seabird 2000 Census (1998-2002). T \&AD Poyser, London.
Raven SJ \& Coulson JC. 1997. The distribution and abundance of Larus gulls nesting on buildings in Britain and Ireland. Bird Study 44: 13-34. https://doi.org/10.1080/00063659709461035

Rock P. 2005. Urban gulls: problems and solutions. British Birds 98: 338-355.

Skórka P, Martyka R, Wójcik JD, Babiarz T \& Skórka J. 20o6. Habitat and nest site selection in the Common Gull Larus canus in southern Poland: significance of man-made habitats for conservation of an endangered species. Acta Ornithologica 41: 137-144. https://doi. org/10.3161/000164506780143889

Snow DW \& Perrins CM. 1998. The Birds of the Western Palearctic. Concise Edition. Vol. 1 Non-Passerines. Oxford University Press, Oxford.

Svensson S, Svensson M \& Tjernberg M. 1999. Swedish Bird Atlas. Vår Fågelvärld, suppl. 31. Sveriges Ornitologiska Förening, Stockholm. (In Swedish.)

\section{Svensk sammanfattning}

Fiskmås Larus canus häckar vanligtvis vid kusten men återfinns i en mängd olika biotoper med tillgång till vatten. Det är känt sedan länge att fiskmåsen även häckar i stadsmiljö, men det saknas dokumentation på hur utbrett det är och hur det har påverkat fiskmåsens beteende. Vi har observerat häckade fiskmåsar i Malmö och intervjuat ordföranden för en bostadsrättsförening om de boendes erfarenheter och observationer. Många har en negativ uppfattning om fiskmåsarna då de anser att fiskmåsarna smutsar ner taken, luktar illa, för oväsen och uppvisar aggressivt beteende under häckningsperioden. Med tanke på fiskmåsars och människors motstridiga intressen krävs bättre dokumentation av häckningspopulationen i stadsmiljö samt dokumentation av måsarnas beteende och interaktion med människor.

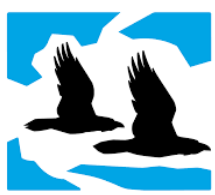

Birdlife Sverige

Ornis Svecica (ISSN 2003-2633) is an open access, peer-reviewed scientific journal published in English and Swedish by BirdLife Sweden. It covers all aspects of ornithology, and welcomes contributions from scientists as well as non-professional ornithologists. Accepted articles are published at no charge to the authors. Read papers or make a submission at https://os.birdlife.se.

Ornis Svecica (ISSN 2003-2633) är en fritt tillgänglig granskad vetenskaplig tidskrift som ges ut på svenska och engelska av BirdLife Sverige. Den täcker ornitologins alla områden och välkomnar bidrag från såväl forskare som icke-professionella ornitologer. Accepterade uppsatser publiceras utan kostnad för författarna. Läs uppsatser eller skicka in ditt bidrag på https://os.birdlife.se. 